\title{
Long-Term Use of Antihypertensive Agents and Risk of Breast Cancer: A Population-Based Case-Control Study
}

Henry W. C. Leung • Li-Ling Hung •

Agnes L. F. Chan $\cdot$ Chih-Hsin Mou

To view enhanced content go to www.cardiologytherapy-open.com

Received: December 22, 2014 / Published online: February 6, 2015

(c) The Author(s) 2015. This article is published with open access at Springerlink.com

\section{ABSTRACT}

Introduction: To evaluate the risk of breast cancer associated with long-term use of antihypertensive agents (AHs) in Taiwanese women with hypertension.

Methods: A search of the Taiwan National Health Insurance Research Database identified 330,699 patients with hypertension who were treated with antihypertensive drugs between January 1, 1998 and December 31, 2011. Logistic regression models were used to estimate the odds ratios (ORs) and 95\% confidence intervals (CIs) between the use of AHs and breast cancer risk, adjusted for other

H. W. C. Leung

Department of Radiation Oncology, China Medical University-An Nan Hospital, Tainan, Taiwan

\section{L.-L. Hung}

Department of Long-Term Care, Hsin Sheng College of Medical Care and Management, Taoyuan, Taiwan

\section{A. L. F. Chan (殴}

Department of Pharmacy, China Medical

University-An Nan Hospital, Tainan, Taiwan

e-mail: agnes.lf@gmail.com

C.-H. Mou

Management Office for Health Data, China Medical University Hospital, Taichung, Taiwan types of antihypertensive drugs, statins and comorbidities.

Results: Among the AHs used to treat the hypertensive women enrolled in our study, our analysis revealed that those treated with one specific particular class of beta-blockers (beta-1 selective beta-blockers) had an increased risk for breast cancer. We also found that the ever-use of calcium channel blockers (CCBs; i.e. for 13 years) was associated with breast cancer in an adjusted model (OR 1.09; 95\% CI 1.03-1.16). However, the use of nonselective beta-blockers, selective and nonselective alpha-blockers, angiotensinconverting enzyme inhibitors and angiotensin II antagonists were not associated with breast cancer risk.

Conclusion: Based on the results of our analysis, long-term use of CCBs or beta- 1 selective beta-blockers are likely to be associated with the risk of breast cancer. Further large comprehensive population-based studies to support our findings are required for confirmation of this conclusion.

Keywords: Beta blockers; Nonselective beta-1 blocker; Long-term; Hypertension 


\section{INTRODUCTION}

Cardiac disease and hypertension have been the third and eighth leading causes of death in Taiwan since 2000 [1]. According to a recent study, the percentage of the population with a prescription for antihypertensive drugs in Taiwan has increased from 2001 to 2006 [2]. The authors of this study report that during this period, the average annual increase in prescriptions for calcium channel blockers (CCBs), angiotensin II receptor blockers (ARBs) and angiotensin-converting-enzyme inhibitors (ACEIs) were 10.7, 22.1 and $4.5 \%$, respectively [2]. In 2013, the sale volume of the three leading antihypertensive drugs in Taiwan amounted to about US\$ 5 million; in comparison, in the USA the value of prescriptions filled for antihypertensive drugs in 2013 totaled about US\$ 678.2 million [3].

The use of antihypertensive agents (AHs) has grown globally over the last decade. However, available data on a potential association between the use of AHs and risk of breast cancer are conflicting. Recent epidemiological studies suggest that beta-blockers prevent breast cancer progression or reduce recurrence and then improve survival [4-6]. In contrast, other studies have reported an increased risk or no association at all between the use of betablockers/CCBs and breast cancer risk [7-9]. In addition, evidence for any association between the use of ACEIs/ARBs and breast cancer is also inconsistent, with some studies suggesting that ACEIs/ARBs are not associated with cancer risk $[10,11]$, and others reporting an increased or reduced risk [12].

To address the conflicting evidence from previous studies, the aim of the study reported here was to evaluate the risk of breast cancer associated with long-term use of AHs in hypertensive women.

\section{METHODS}

\section{Data Source}

Data were retrieved from the National Health Insurance Research Database (NHIRD) and Registry for Catastrophic Illness Patient dataset (HV dataset) between January 1, 1998 and December 31, 2011 in Taiwan. The NHIRD contains comprehensive information on demographic characteristics, pharmacy records and medical services from inpatient, outpatient and emergency care under a national health insurance program in which over $99 \%$ of the 23 million inhabitants of Taiwan are enrolled. The HV dataset comprises specific data subsets of the NHIRD for research purposes and contains registration files and original claim data on patients registered in the NHIRD who have/had a catastrophic illness. All patients records/ information were de-identified and analyzed anonymously. Therefore, this study was exempt from the approval by the Ethics Review Board at our institution.

\section{Study Group}

From the HV dataset, we identified 330,699 women with newly diagnosed hypertension [International Classification of Disease, Ninth Revision (ICD-9 CM) codes 401-405] who had been treated with any AHs continuously for at least 6 months between January 1, 1998 and December 31, 2011. Among these, we further identified women with a first diagnosis of breast cancer (ICD-9 CM codes 174.xx and 175.xx); these women were the cases in our study (Fig. 1). The date of diagnosis was the index date.

We excluded patients who had a history of breast cancer or any cancer recorded in the HV 


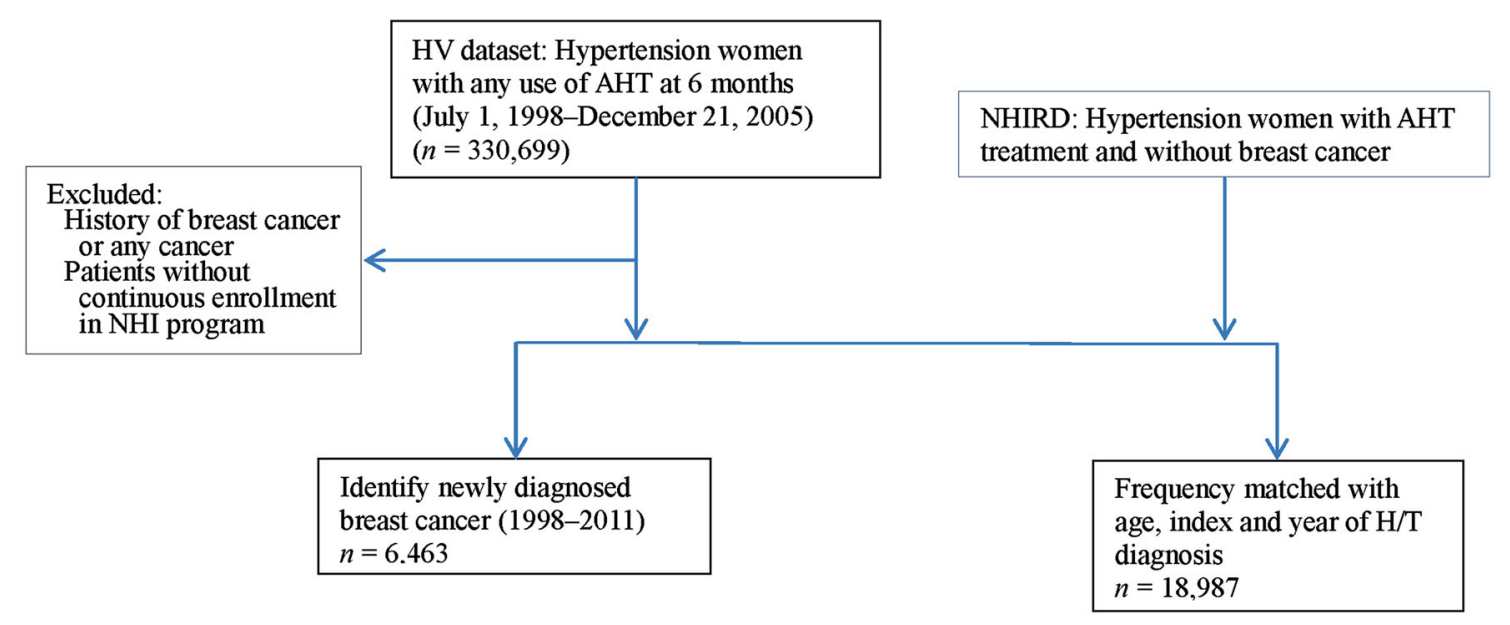

Fig. 1 Study flow diagram. AHT Antihypertensive, $H / T$ hypertension, $H V$ Registry for Catastrophic Illness Patient dataset, NHIRD National Health Insurance Research Database

dataset any time before the initiation of antihypertensive treatment and patients without continuous enrolment in a NHI program. Patients were followed from the date of diagnosis of hypertension in 1998 up to December 31, 2011 (median duration 13 years) or death, whichever came first (Fig. 1).

We randomly selected hypertensive women registered in the NHIRD without any diagnosis of breast cancer who were receiving treatment for hypertension in the same period as the cases. These were matched (1:4) for age (5-year categories), index date and year of hypertension diagnosis with the cases to establish the control group (Fig. 1).

\section{Exposure Variables}

The main exposure of interest was that to betablocker, CCB, ACEI and ARB therapy. We collected information on prescribed drug types according to Anatomical Therapeutic Chemical Classification System codes (C07 for betablockers; C02D, C08C, C08D, C08DA51 for CCBs; C02E, C02L, C09A, C09BA for ACEIs;
C09CA for ARBs), dosage, date of prescription, supply days and total number of prescriptions from the outpatient and inpatient records [13]. The cumulative defined daily dose (cDDD) of each AH was calculated as recommended by the World Health Association [14]. Beta-blockers were further classified as nonselective and beta1 selective beta-blockers, and as selective and nonselective alpha-blockers.

\section{Potential Covariates}

Several potential covariates, including age and comorbidities at cancer diagnosis, were also measured in the year preceding the index date. Other covariates tested included the use of statins and hormone replacement therapy.

\section{Sensitivity Analysis}

We evaluated the sensitivity effects by changing the inclusion criteria of drug prescription for three types of $\mathrm{AH}$ beginning at least from 6-9 months before the index date. 


\section{Statistical Analysis}

Logistic regression was used to estimate the crude and adjusted odds ratio (OR) and 95\% confidence interval (CI) for breast cancer risk. We calculated a running sum of the duration and DDD of each drug from the date of the initial $\mathrm{AH}$ prescription to the index date. We categorized the cumulative use for each patient as follows: $\leq 1,1-2,2-3$ and $\geq 3$ years of duration. Cumulative DDD of each AH was classified by quartile. Multivariable logistical regression was used to adjust the covariates. We also estimated the trend of the duration and cDDD of each drug use. Data were analyzed using the SAS Statistical Package, version 9.3 (SAS Institute, Cary, NC). The significance level was set at $P<0.05$ (two-tailed test).

\section{RESULTS}

We identified 6,463 hypertensive women with breast cancer as cases and 18,987 hypertensive women without breast cancer as controls. Among the 6,463 cases, the most commonly prescribed AHs was CCBs (52.8\%), followed by ACEIs (45.5\%) and beta-blockers (41.1\%) (Table 1). No significant differences in age and mean Charlson comorbidity score $(P>0.05)$ were found between cases and controls. Everuse of CCBs and beta-blockers for longer than 10 years was significantly associated with breast cancer (OR 1.09; 95\% CI 1.03-1.16) in an adjusted model. The risk of breast cancer was even higher in patients receiving hormone replacement therapy (OR 1.28, 95\% CI 1.18-1.39) and statins (OR 1.68, $95 \%$ CI 1.50-1.83) (Table 1).

When we stratified the risk of breast cancer associated with different sub-types of betablockers, we found a statistically significant risk of breast cancer with most beta-1 selective beta-blockers, such as atenolol (OR 1.14; 95\% CI 1.05-1.25) acebutolol (OR 1.29; 1.00-1.66) and bisoprolol (OR 1.08; 1.01-1.16) (Fig. 2). The non-selective beta-blockers, alpha-selective and beta-non selective showed no significant association with breast cancer (Fig. 2).

We then stratified beta-blocker, ARB and CCB users by exposure duration and the cumulative DDD. The results show that the risk of breast cancer was significantly increased in beta-blocker and CCB users with increasing exposure duration and increasing cDDD compared to the controls [trend test for betablocker users: $P=0.003$ (exposure duration), $P=0.0003$ (cDDD); trend test for CCB users: $P=0.006 \quad$ (exposure duration), $\quad P=0.002$ (cDDD)] (Table 2).

The risk of breast cancer increased with everuse of atenolol or acebutolol (Table 3). This risk increased with increasing exposure,duration of use (trend test: $P=0.0003$ for atenolol; $P=0.01$ for acebutolol) and cDDD (trend test: $P=0.002$ for atenolol; $P=0.02$ for acebutolol).

In the sensitivity analysis for exposure duration of AHs, the results were unchanged when the inclusion criteria of $\mathrm{AH}$ prescription was changed from $<6$ to $>9$ months (Table 4 ).

\section{DISCUSSION}

The results of this study suggest that the use of ACEi, ARBs, and nonselective beta-adrenergic receptor antagonists (propranolol or carteolol) is not associated with breast cancer. These results are consistent with those of most observational studies [10, 11].

We also found that CCBs and the beta- 1 selective beta-blockers acebutolol, atenolol and bisoprolol may increase the risk of breast cancer. This finding seems to differ from those 
Table 1 Characteristics of hypertensive patients with breast cancer and non-breast cancer during the study period (1998-2011)

\begin{tabular}{|c|c|c|c|c|c|c|}
\hline \multirow[t]{2}{*}{ Characteristic } & \multicolumn{2}{|c|}{ Case $(N=6,463)$} & \multicolumn{2}{|c|}{ Control $(N=18,987)$} & \multicolumn{2}{|c|}{ Odds ratio $(95 \% \mathrm{CI})$} \\
\hline & $n$ & $\%$ & $n$ & $\%$ & Crude & Adjusted \\
\hline Mean age, years (SD) & 61.9 & $(10.7)$ & 61.9 & $(10.9)$ & & \\
\hline $18-44$ & 272 & 4.21 & 785 & 4.13 & & \\
\hline $45-54$ & 1,489 & 23.0 & 4,409 & 23.2 & & \\
\hline $55-64$ & 2,320 & 35.9 & 6,729 & 35.4 & & \\
\hline $65-74$ & 1,610 & 24.9 & 4,778 & 25.2 & & \\
\hline $75-84$ & 645 & 9.98 & 1,912 & 10.1 & & \\
\hline $85+$ & 127 & 1.97 & 374 & 1.97 & & \\
\hline Menopause & 4,702 & 72.7 & 13,793 & 72.6 & & \\
\hline Mean CCI score (SD) & 0.33 & $(0.87)$ & 0.34 & $(0.92)$ & $0.98(0.95-1.01)$ & - \\
\hline Diabetes & 1,761 & 27.3 & 4,803 & 25.3 & $1.11(1.04-1.18)^{* *}$ & $1.08(1.02-1.16)^{*}$ \\
\hline Hyperlipidemia & 3,196 & 49.5 & 9,207 & 48.5 & $1.04(0.98-1.10)$ & - \\
\hline \multicolumn{7}{|l|}{ Ever users of HRT } \\
\hline No & 5,450 & 84.3 & 16,626 & 87.6 & 1.00 (Reference) & 1.00 (Reference) \\
\hline Yes & 1,013 & 15.7 & 2,361 & 12.4 & $1.31(1.21-1.42)^{* * *}$ & $1.28(1.18-1.39)^{* * *}$ \\
\hline \multicolumn{7}{|l|}{ Ever users of statins } \\
\hline No & 5,725 & 88.6 & 17,700 & 93.2 & 1.00 (Reference) & 1.00 (Reference) \\
\hline Yes & 738 & 11.4 & 1,287 & 6.78 & $1.77(1.61-1.95)^{* * *}$ & $1.68(1.52-1.85)^{* * *}$ \\
\hline \multicolumn{7}{|l|}{ Types of AHT } \\
\hline \multicolumn{7}{|l|}{ ACEI } \\
\hline No & 3,520 & 54.5 & 10,152 & 53.5 & 1.00 (Reference) & \\
\hline Yes & 2,943 & 45.5 & 8,835 & 46.5 & $0.96(0.91-1.02)$ & - \\
\hline \multicolumn{7}{|l|}{$\mathrm{ARB}$} \\
\hline No & 4,682 & 72.4 & 14,290 & 75.3 & 1.00 (Reference) & 1.00 (Reference) \\
\hline Yes & 1,781 & 27.6 & 4,697 & 24.7 & $1.16(1.09-1.23)^{* * *}$ & $1.04(0.98-1.12)$ \\
\hline \multicolumn{7}{|l|}{ CCBs } \\
\hline No & 3,052 & 47.2 & 9,697 & 51.1 & 1.00 (Reference) & 1.00 (Reference) \\
\hline Yes & 3,411 & 52.8 & 9,290 & 48.9 & $1.17(1.10-1.23)^{* * *}$ & $1.09(1.03-1.16)^{* *}$ \\
\hline \multicolumn{7}{|l|}{ Beta-blocker } \\
\hline No & 3,806 & 58.9 & 11,721 & 61.7 & 1.00 (Reference) & 1.00 (Reference) \\
\hline
\end{tabular}


Table 1 continued

\begin{tabular}{|c|c|c|c|c|c|c|}
\hline \multirow[t]{2}{*}{ Characteristic } & \multicolumn{2}{|c|}{ Case $(N=6,463)$} & \multicolumn{2}{|c|}{ Control $(N=18,987)$} & \multicolumn{2}{|c|}{ Odds ratio $(95 \% \mathrm{CI})$} \\
\hline & $n$ & $\%$ & $n$ & $\%$ & Crude & Adjusted \\
\hline Yes & 2,657 & 41.1 & 7,266 & 38.3 & $1.13(1.06-1.19)^{* * *}$ & $1.05(0.99-1.12)$ \\
\hline
\end{tabular}

${ }^{*} P<0.05,{ }^{* *} P<0.01,{ }^{* * *} P<0.001$

$S D$ Standard deviation, CCI Charlson comorbidity index, HRT hormone replacement therapy, $A H T$ Antihypertensive therapy, $A C E I$ angiotensin-converting-enzyme inhibitor, $A R B$ angiotensin receptor II blocker, $C C B$ calcium channel blocker, $C I$ confidence interval

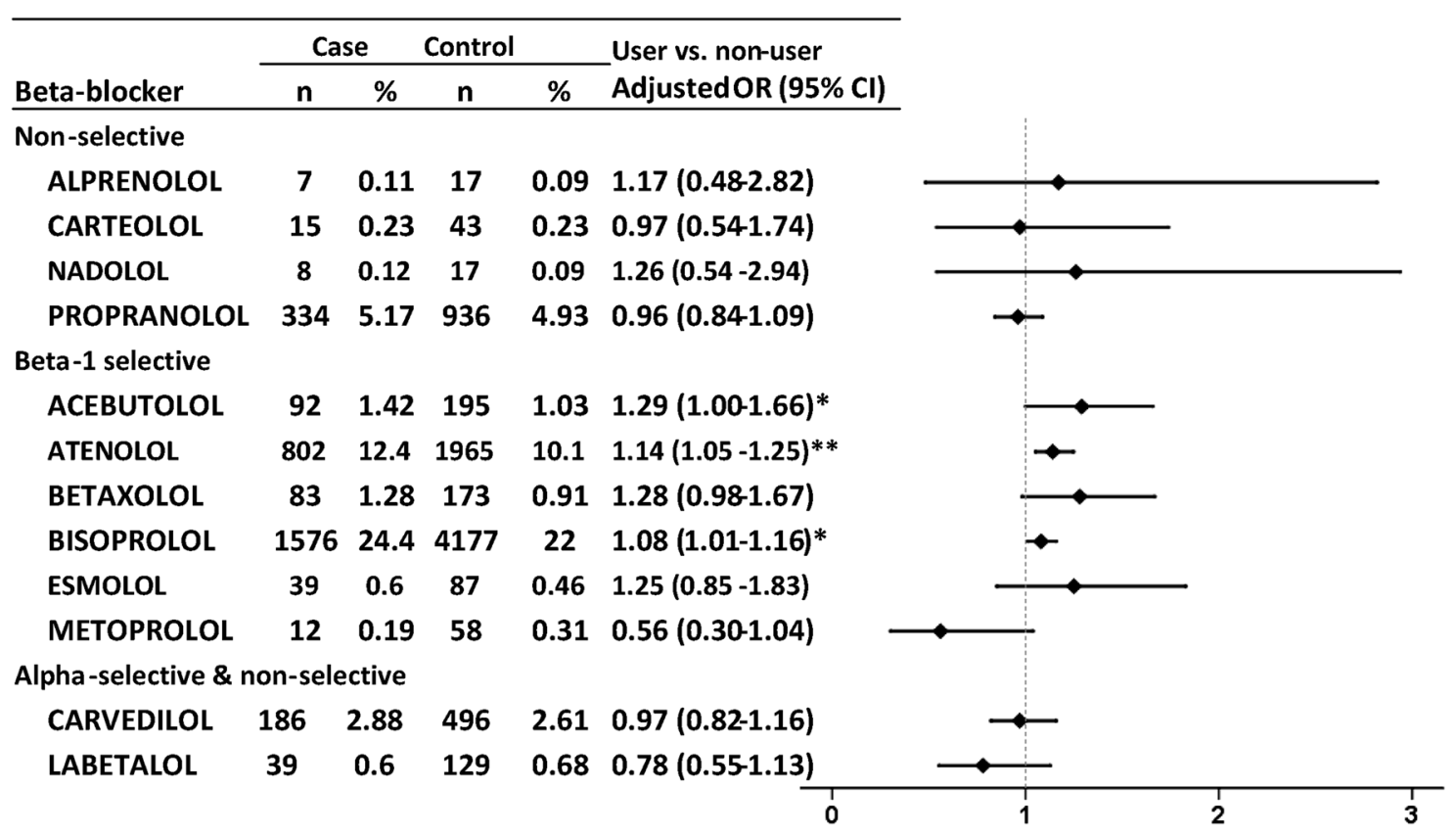

Fig. 2 Forest plot of breast cancer risk associated with use of beta-blockers, 1998-2011. OR Odds ratio, CI confidence interval

of previous studies which reported that beta-1 selective beta-blockers and CCBs had marked protective effects $[15,16]$. However, the authors of a recently published study reported observing a weak inverse association between cardio nonselective beta-blockers and breast cancer risk [9]. However, since the association did not reach statistical significance, the results did not support the hypothesis of beta-blocker usage protecting against breast cancer progression [9]. The results of a recently published network analysis indicated a lack of consistency in the effect of CCBs on breast cancer; this was attributed to the short duration of the followup in the trials included in the network metaanalysis [7].

The results of previous preclinical studies are inconclusive in terms of whether beta-blockers have agonist activity in breast cancer growth. Some studies has demonstrated that beta- 2 adrenergic signaling plays a role in several pathways involved in breast tumor progression and metastasis $[17,18]$, but others have found that beta-adrenergic receptor (AR) stimulation may both inhibit and promote breast tumor growth [19-23]. A recently published study adds 
Table 2 Odds risk and 95\% confidence intervals for risk of breast cancer associated with exposure to different types of antihypertensives, duration of exposure and dosage

\begin{tabular}{|c|c|c|c|c|}
\hline \multirow{2}{*}{$\begin{array}{l}\text { Type of antihypertensive } \\
\text { agent }\end{array}$} & \multirow{2}{*}{$\begin{array}{l}\text { No. of study } \\
\text { subjects }\end{array}$} & \multirow{2}{*}{$\begin{array}{l}\text { No. of breast } \\
\text { cancer cases }\end{array}$} & \multicolumn{2}{|c|}{ Multivariable-adjusted odds ratio } \\
\hline & & & $\begin{array}{l}\text { Odds ratio } \\
(95 \% \mathrm{CI})\end{array}$ & $\begin{array}{l}P \text { for } \\
\text { trend }\end{array}$ \\
\hline \multicolumn{5}{|l|}{ Any beta-blocker ${ }^{a}$} \\
\hline Never use & 15,527 & 3,806 & 1.00 (Reference) & \\
\hline Ever-use exposure duration (years) & & & & 0.003 \\
\hline$\leq 1$ & 2,085 & 521 & $0.99(0.89-1.11)$ & \\
\hline $1-2$ & 2,300 & 548 & $0.91(0.82-1.01)$ & \\
\hline $2-3$ & 1,512 & 402 & $1.03(0.92-1.17)$ & \\
\hline$>3$ & 4,026 & 1,186 & $1.16(1.07-1.26)^{* * *}$ & \\
\hline Cumulative DDD ${ }^{\mathrm{b}}$ & & & & 0.0003 \\
\hline $\mathrm{cDDD}<\mathrm{Q} 1$ & 2,480 & 597 & $0.93(0.84-1.02)$ & \\
\hline $\mathrm{Q} 1 \leq \mathrm{cDDD}<\mathrm{Q} 2$ & 2,482 & 621 & $0.97(0.88-1.07)$ & \\
\hline $\mathrm{Q} 2 \leq \mathrm{cDDD}<\mathrm{Q} 3$ & 2,480 & 684 & $1.08(0.98-1.19)$ & \\
\hline $\mathrm{cDDD} \geq \mathrm{Q} 4$ & 2,481 & 755 & $1.22(1.11-1.34)^{* * *}$ & \\
\hline \multicolumn{5}{|l|}{ Any $\mathrm{ARB}^{\mathrm{c}}$} \\
\hline Never use & 18,972 & 4,682 & 1.00 (Reference) & \\
\hline Ever-use exposure duration (years) & & & & 0.71 \\
\hline$\leq 1$ & 1,355 & 370 & $1.05(0.93-1.19)$ & \\
\hline $1-2$ & 1,652 & 439 & $1.00(0.89-1.12)$ & \\
\hline $2-3$ & 1,083 & 288 & $0.98(0.85-1.12)$ & \\
\hline$>3$ & 2,388 & 684 & $1.03(0.93-1.14)$ & \\
\hline Cumulative $\mathrm{DDD}^{\mathrm{b}}$ & & & & 0.53 \\
\hline $\mathrm{cDDD}<\mathrm{Q} 1$ & 1,618 & 444 & $1.06(0.94-1.19)$ & \\
\hline $\mathrm{Q} 1 \leq \mathrm{cDDD}<\mathrm{Q} 2$ & 1,621 & 414 & $0.95(0.84-1.07)$ & \\
\hline $\mathrm{Q} 2 \leq \mathrm{cDDD}<\mathrm{Q} 3$ & 1,618 & 441 & $1.00(0.89-1.13)$ & \\
\hline $\mathrm{cDDD} \geq \mathrm{Q} 4$ & 1,621 & 482 & $1.07(0.95-1.21)$ & \\
\hline \multicolumn{5}{|l|}{ Any $\mathrm{CCB}^{\mathrm{d}}$} \\
\hline Never use & 12,749 & 3,052 & 1.00 (Reference) & \\
\hline Ever-use exposure duration (years) & & & & 0.006 \\
\hline$\leq 1$ & 2,257 & 572 & $1.05(0.94-1.16)$ & \\
\hline $1-2$ & 2,662 & 696 & $1.08(0.98-1.19)$ & \\
\hline $2-3$ & 1,958 & 522 & $1.09(0.98-1.22)$ & \\
\hline
\end{tabular}


Table 2 continued

\begin{tabular}{|c|c|c|c|c|}
\hline \multirow{2}{*}{$\begin{array}{l}\text { Type of antihypertensive } \\
\text { agent }\end{array}$} & \multirow{2}{*}{$\begin{array}{l}\text { No. of study } \\
\text { subjects }\end{array}$} & \multirow{2}{*}{$\begin{array}{l}\text { No. of breast } \\
\text { cancer cases }\end{array}$} & \multicolumn{2}{|c|}{ Multivariable-adjusted odds ratio } \\
\hline & & & $\begin{array}{l}\text { Odds ratio } \\
\text { (95 \% CI) }\end{array}$ & $\begin{array}{l}P \text { for } \\
\text { trend }\end{array}$ \\
\hline$>3$ & 5,852 & 1,621 & $1.11(1.03-1.19)^{* *}$ & \\
\hline Cumulative $\mathrm{DDD}^{\mathrm{b}}$ & & & & 0.002 \\
\hline $\mathrm{cDDD}<\mathrm{Q} 1$ & 3,175 & 818 & $1.05(0.96-1.15)$ & \\
\hline $\mathrm{Q} 1 \leq \mathrm{cDDD}<\mathrm{Q} 2$ & 3,176 & 834 & $1.07(0.98-1.18)$ & \\
\hline $\mathrm{Q} 2 \leq \mathrm{cDDD}<\mathrm{Q} 3$ & 3,174 & 838 & $1.06(0.97-1.17)$ & \\
\hline $\mathrm{cDDD} \geq \mathrm{Q} 4$ & 1,621 & 482 & $1.16(1.06-1.28)^{* *}$ & \\
\hline
\end{tabular}

${ }^{* *} P<0.01,{ }^{* * *} P<0.001$

$c D D D$ Cumulative defined daily dose

${ }^{a}$ Adjusted for peripheral vascular disease, diabetes mellitus and medicine use (included HRT, statin, ARB and CCB)

b Beta-blocker: Q1 (25\%) = 195.25 DDD, Q2 (50\%) = 448 DDD, Q3 (75\%) =1,012 DDD. CCB: Q1 (25\%) = 390.1 DDD, Q2 (50\%) = 851 DDD, Q3 (75\%) =1,641.3 DDD. ARB: Q1 (25\%) = 405 DDD, Q2 (50\%) = 800.5 DDD, Q3 $(75 \%)=1,464 \mathrm{DDD}$

${ }^{c}$ Adjusted for peripheral vascular disease, diabetes mellitus and medicine use (including HRT, statin, beta-blocker and $\mathrm{CCB})$

d Adjusted for peripheral vascular disease, diabetes mellitus and medicine use (including HRT, statin, beta-blocker and $\mathrm{ARB}$ )

further to the body of evidence on the effect of agonist type, indicating that the beta 2-AR antagonist in particular seems to be the most cytotoxic beta-blocker in non-stimulated cancer cells [24]. However, the majority of clinical observational studies carried out to date have focused on comparing the association between the use of propranolol or atenolol and breast cancer risk or mortality and have not explored the relationship between the subtype of beta-AR expression and breast cancer risk $[25,26]$. Our study is the first from Asia to report that treatment with the beta- 1 selective blockerbut not the nonselective $\beta 1 / \beta$ blocker-may increase the risk of breast cancer (Fig. 2). These results appear to be consistent with those of preclinical studies suggesting that the effects of beta-adrenergic signaling on tumor progression and metastasis are inhibited by the $\beta 2$-receptor antagonists but not by $\beta 1$ antagonists [18-24]. Consequently, better designed observational studies or randomized controlled trials are required before this type of beta-blocker can be considered as a therapeutic option for patients with breast cancer.

We also observed that CCBs are likely to be associated with breast cancer risk. This finding is consistent with those from a recently published study performed by Li et al. [3]. Both studies seem to revive an earlier previous hypothesis and focus on the long-term use of CCBs among current or ever-users (10 years if the study of Li et al. [3]; 13 years in our study). However, other previously published studies found no increased risk of breast cancer associated with CCB use [25, 26]. Therefore, to date, the results on the effect of CCBs on breast cancer risk are inconsistent. Again, larger and more comprehensive studies are needed to confirm the effects of long-term use of CCBs on breast cancer.

A major advantage of our study was that we collected information prospectively on 
Table 3 Breast cancer risk associated with exposure duration and dosage of specific beta-blockers during the study period (1998-2011)

\begin{tabular}{|c|c|c|c|c|c|c|}
\hline \multirow[t]{2}{*}{ Variable } & \multicolumn{2}{|c|}{ Acebutolol } & \multicolumn{2}{|l|}{ Atenolol } & \multicolumn{2}{|l|}{ Bisoprolol } \\
\hline & $n / N$ & $\begin{array}{l}\text { Odds ratio } \\
(95 \% \mathrm{CI})\end{array}$ & $\overline{n / N}$ & $\begin{array}{l}\text { Odds ratio } \\
(95 \% \mathrm{CI})\end{array}$ & $\overline{n / N}$ & $\begin{array}{l}\text { Odds ratio } \\
(95 \% \mathrm{CI})\end{array}$ \\
\hline \multicolumn{7}{|c|}{ Duration of exposure to antihypertensive agent } \\
\hline $\begin{array}{l}\text { AHT non- } \\
\text { use }\end{array}$ & $\begin{array}{l}6,371 / \\
25,163\end{array}$ & 1.00 (Reference) & $\begin{array}{l}5,661 / \\
22,683\end{array}$ & 1.00 (Reference) & $\begin{array}{c}4,887 / \\
19,697\end{array}$ & 1.00 (Reference) \\
\hline \multicolumn{7}{|c|}{ Exposure duration (years) } \\
\hline$\leq 1$ & $30 / 104$ & $1.10(0.71-1.68)$ & $248 / 942$ & $1.01(0.87-1.17)$ & $1,318 / 4,913$ & $1.06(0.99-1.14)$ \\
\hline $2-3$ & $21 / 71$ & $1.10(0.66-1.84)$ & $222 / 795$ & $1.07(0.91-1.26)$ & $121 / 402$ & $1.14(0.92-1.42)$ \\
\hline $3-4$ & $17 / 52$ & $1.37(0.77-2.46)$ & $120 / 423$ & $1.08(0.87-1.34)$ & $57 / 179$ & $1.24(0.90-1.70)$ \\
\hline$>3$ & $24 / 60$ & $\begin{array}{l}1.85 \\
\quad(1.10-3.12)^{*}\end{array}$ & $212 / 607$ & $\begin{array}{l}1.43 \\
\quad(1.20-1.70)^{* * *}\end{array}$ & $80 / 259$ & $1.12(0.86-1.47)$ \\
\hline$P$ for trend & & 0.01 & & 0.0003 & & 0.03 \\
\hline \multicolumn{7}{|c|}{ Dosage $(\mathrm{cDDD})^{\mathrm{a}}$} \\
\hline$<\mathrm{Q} 1$ & $21 / 71$ & $1.10(0.66-1.84)$ & $187 / 891$ & $1.04(0.87-1.23)$ & $384 / 1457$ & $1.04(0.92-1.18)$ \\
\hline$\geq \mathrm{Q} 1-<\mathrm{Q} 2$ & $19 / 72$ & $0.97(0.57-1.64)$ & $187 / 689$ & $1.03(0.87-1.23)$ & $408 / 1429$ & $\begin{array}{l}1.14 \\
\quad(1.01-1.29)^{*}\end{array}$ \\
\hline$\geq \mathrm{Q} 2-<\mathrm{Q} 3$ & $26 / 72$ & $1.56(0.96-2.53)$ & $202 / 695$ & $1.13(0.96-1.34)$ & $382 / 1435$ & $1.02(0.90-1.15)$ \\
\hline$\geq \mathrm{Q} 3$ & $26 / 72$ & $1.59(0.98-2.58)$ & $226 / 692$ & $1.30(1.10-1.53)^{* *}$ & $402 / 1432$ & $1.10(0.98-1.25)$ \\
\hline$P$ for trend & & 0.02 & & 0.002 & & 0.053 \\
\hline
\end{tabular}

${ }^{*} P<0.05,{ }^{* *} P<0.01,{ }^{* * *} P<0.001$

Adjusted for diabetes mellitus and medicine use (including HRT, statins, ARBs and CCBs)

$n$ Number of breast cancer patients using a specific AHT, $N$ total number of study population using a specific AHT

a Beta-blocker: Q1 $(25 \%)=195.25$ DDD, Q2 $(50 \%)=448$ DDD, Q3 (75\%) =1,012 DDD. CCB: Q1 (25\%)=390.1 DDD, Q2 (50\%) = 851 DDD, Q3 (75\%) = 1,641.3 DDD. ARB: Q1 (25\%) = 405 DDD, Q2 (50\%) = 800.5 DDD, Q3 $(75 \%)=1,464 \mathrm{DDD}$

healthcare beneficiaries registered in a large population-based database for whom complete data on drug prescriptions and cancer diagnoses were available. Thus, the possibility of selection and information biases was minimized. However, there were still some limitations to our study. First, the health insurance database that we used was developed for administrative purposes and contained de-identified records of each individual registered. Second, the database only provided information on the frequency and classes of prescribed medications and did not provide any clinical laboratory data or clinical information; therefore, we could not estimate patient's responses to drug therapy. Finally, the database did not contain information on various lifestyle risk factors for cancer, such as physical activity, alcohol consumption, smoking, body mass index, socioeconomic status and diet; therefore, these were not included in the analysis. Although we adjusted the potential covariates, such as co- 
Table 4 Sensitivity analysis for criteria of antihypertensive use

\begin{tabular}{|c|c|c|c|c|c|c|}
\hline \multirow[t]{2}{*}{ Variable } & \multicolumn{2}{|c|}{ Any beta-blocker ${ }^{a}$} & \multicolumn{2}{|l|}{ Any $A^{\prime R B}{ }^{b}$} & \multicolumn{2}{|l|}{ Any $\mathbf{C C B}^{\mathrm{c}}$} \\
\hline & $\overline{n / N}$ & $\begin{array}{l}\text { Odds ratio } \\
\text { (95\% CI) }\end{array}$ & $\overline{n / N}$ & $\begin{array}{l}\text { Odds ratio } \\
(95 \% \mathrm{CI})\end{array}$ & $\overline{n / N}$ & $\begin{array}{l}\text { Odds ratio } \\
(95 \% \mathrm{CI})\end{array}$ \\
\hline Non-user & $4,107 / 16,690$ & 1.00 (Reference) & $4,876 / 19,700$ & 1.00 (Reference) & $3,367 / 14,012$ & 1.00 (Reference) \\
\hline User & $2,356 / 8,760$ & $1.04(0.98-1.11)$ & $1,587 / 5,750$ & $1.01(0.94-1.09)$ & $3,096 / 11,438$ & $1.09(1.03-1.16)^{* *}$ \\
\hline \multicolumn{7}{|c|}{ Drug use (years) } \\
\hline$\leq 2$ & $220 / 922$ & $0.94(0.80-1.10)$ & $176 / 627$ & $1.08(0.90-1.29)$ & $257 / 994$ & $1.07(0.92-1.24)$ \\
\hline $2-3$ & $548 / 2,300$ & $0.91(0.82-1.01)$ & $439 / 1,652$ & $1.00(0.89-1.12)$ & $696 / 2,662$ & $1.07(0.98-1.18)$ \\
\hline $3-4$ & $402 / 1,512$ & $1.03(0.91-1.16)$ & $288 / 1,083$ & $0.97(0.84-1.12)$ & $522 / 1,958$ & $1.09(0.98-1.22)$ \\
\hline$>4$ & $1,186 / 4,026$ & $1.15(1.06-1.25)^{* * *}$ & $684 / 2,388$ & $1.03(0.93-1.14)$ & $1,621 / 5,824$ & $1.11(1.03-1.19)^{* *}$ \\
\hline$P$ for trend & & 0.005 & & 0.76 & & 0.005 \\
\hline
\end{tabular}

${ }^{*} P<0.05,{ }^{* *} P<0.01,{ }^{* * *} P<0.001$

$N$ Total number of study population using specific AHT, $n$ number of breast cancer patients using specific AHT

${ }^{a}$ Adjusted for peripheral vascular disease, diabetes mellitus and medicine use (including HRT, statins, ARBs and CCBs)

b Adjusted for peripheral vascular disease, diabetes mellitus and medicine use (including HRT, statins, beta-blockers and CCBs)

${ }^{c}$ Adjusted for peripheral vascular disease, diabetes mellitus and medicine use (including HRT, statins, beta-blockers and ARBs)

morbidities and the use of other medications, the misclassification of these covariates may have some impact on our results.

\section{CONCLUSION}

Our findings indicate that the long-term use of CCBs or beta-1 selective blockers are likely to be associated with breast cancer risk. Further comprehensive and large populationbased studies are needed to confirm these findings before any definitive conclusion can be drawn.

\section{ACKNOWLEDGMENTS}

No funding or sponsorship was received for this study or publication of this article. All named authors meet the International Committee of Medical Journal Editors (ICMJE) criteria for authorship for this manuscript, take responsibility for the integrity of the work as a whole, and have given final approval for the version to be published. All authors had access to the data and played a role in writing this manuscript.

Conflict of interest. Henry W. C. Leung, LiLing Hung, Agnes L. F. Chan, and Chih-Hsin Mou declare no conflict of interest.

Compliance with ethics guidelines. All patients records/information were de-identified and analyzed anonymously. Therefore, this study was exempt from the approval by the Ethics Review Board at our institution.

Open Access. This article is distributed under the terms of the Creative Commons Attribution Noncommercial License which permits any noncommercial use, distribution, 
and reproduction in any medium, provided the original author(s) and the source are credited.

\section{REFERENCES}

1. Taiwan Cancer Registry. Available at: http://www. mc.ntu.edu.tw/CRS/main.php?Page=N2.

2. Huang LY, Shau WY, Chen HC, et al. Pattern analysis and variations in the utilization of antihypertensive drugs in Taiwan: a six-year study. Eur Rev Med Pharmacol Sci. 2013;17(3):410-9.

3. Li CI, Daling JR, Tang MT, Haugen KL, Porter PL, Malone KE. Use of antihypertensive medications and breast cancer risk among women aged 55 to 74 years. JAMA Intern Med. 2013;173(17):1629-37.

4. Ganz PA, Habel LA, Weltzien EK, Caan BJ, Cole SW. Examining the influence of beta blockers and ACE inhibitors on the risk for breast cancer recurrence: results from the LACE cohort. Breast Cancer Res Treat. 2011;129:549-56.

5. Ganz PA, Cole SW. Expanding our therapeutic options: beta blockers for breast cancer? J Clin Oncol. 2011;29:2612-6.

6. Powe DG, Entschladen F. Targeted therapies: using beta-blockers to inhibit breast cancer progression. Nat Rev Clin Oncol. 2011;8:511-2.

7. Bangalore S, Kumar S, Kjeldsen SE, et al. Antihypertensive drugs and risk of cancer: network meta-analyses and trial sequential analyses of 324,168 participants from randomised trials. Lancet Oncol. 2011;12(1):65-82.

8. Shah SM, Carey IM, Owen CG, Harris T, Dewilde S, Cook DG. Does beta adrenoceptor blocker therapy improve cancer survival? Findings from a population based retrospective cohort study. Br J Clin Pharmacol. 2011;72:157-61.

9. Cardwell CR, Coleman HG, Murray LJ, Entschladen F, Powe DG. Beta-blocker usage and breast cancer survival: a nested case-control study within a UK Clinical Practice Research Datalink cohort. Int J Epidemiol. 2013;42(6):1852-61.

10. The ARB Trialists Collaboration. Effects of telmisartan, irbesartan, valsartan, candesartan, and losartan on cancers in 15 trials enrolling 138,769 individuals. J Hypertens. 2011;29:623-35.

11. Pasternak B, Svanström H, Callréus T, Melbye M, Hviid A. Use of angiotensin receptor blockers and the risk of cancer. Circulation. 2011;123:1729-36.
12. Sipahi I, Debanne SM, Rowland DY, Simon DI, Fang JC. Angiotensin-receptor blockade and risk of cancer: meta-analysis of randomised controlled trials. Lancet Oncol. 2010;11:627-36.

13. WHO Collaborating Centre for Drug Statistics Methodology. Application for ATC codes. Available at: http://www.whocc.no/atc/ application_for_atc_codes/.

14. Charlson ME, Pompei P, Ales KL, MacKenzie CR. A new method of classifying prognostic comorbidity in longitudinal studies: development and validation. J Chronic Dis. 1987;40:373-83.

15. Powe DG, Voss MJ, Zänker KS, et al. Beta-blocker drug therapy reduces secondary cancer formation in breast cancer and improves cancer specific survival. Oncotarget. 2010;1(7):628-38.

16. Melhem-Bertrandt A, Chavez-Macgregor M, Lei X, et al. Beta-blocker use is associated with improved relapse-free survival in patients with triple-negative breast cancer. J Clin Oncol. 2011;29:2645-52.

17. Drell TL 4th, Joseph J, Lang K, Manni A. Effects of neurotransmitters on the chemokinesis and chemotaxis of MDA-MB-468 human breast carcinoma cells. Breast Cancer Res Treat. 2003;80:63-70.

18. Lang K, Drell TL 4th, Lindecke A, Niggemann B, Kaltschmidt C. Induction of a metastatogenic tumor cell type by neurotransmitters and its pharmacological inhibition by established drugs. Int J Cancer. 2004;112:231-8.

19. Slotkin TA, Zhang J, Dancel R. Beta-adrenoceptor signaling and its control of cell replication in MDAMB-231 human breast cancer cells. Breast Cancer Res Treat. 2000;60:153-66.

20. Carie AE, Sebti SM. A chemical biology approach identifies a beta- 2 adrenergic receptor agonist that causes human tumor regression by blocking the Raf-1/ Mek-1/Erk1/2 pathway. Oncogene. 2007;26:3777-88.

21. Cakir Y, Plummer HK 3rd, Tithof PK, Schuller HM. Beta-adrenergic and acid-mediated growth regulation of human breast cancer cell lines. Int J Oncol. 2002;21:153-7.

22. Sloan EK, Priceman SJ, Cox BF, et al. The sympathetic nervous system induces a metastatic switch in primary breast cancer. Cancer Res. 2010;70:7042-52.

23. Madden KS, Szpunar MJ, Brown EB. $\beta$-Adrenergic receptors ( $\beta$-AR) regulate VEGF and IL-6 production by divergent pathways in high $\beta$-AR-expressing breast cancer cell lines. Breast Cancer Res Treat. 2011;130:747-58. 
24. Işeri OD, Sahin FI, Terzi YK, Yurtcu E, Erdem SR, Sarialioglu F. beta-Adrenoreceptor antagonists reduce cancer cell proliferation, invasion, and migration. Pharm Biol. 2014;52(11):1374-81.

25. Saltzman BS, Weiss NS, Sieh W, et al. Use of antihypertensive medications and breast cancer risk. Cancer Causes Control. 2013;24(2):365-71.
26. Chen $\mathrm{Q}$, Zhang $\mathrm{Q}$, Zhong $\mathrm{F}$, et al. Association between calcium channel blockers and breast cancer: a meta-analysis of observational studies. Pharmacoepidemiol Drug Saf. 2014;23(7):711-8. 